\title{
INVESTMENT IN HIGHER EDUCATION AND ECONOMIC DEVELOPMENT IN EAST ASIA
}

\author{
Thi Hoai Trinh NGUYEN ${ }^{a *}$, Claudiu CICEA ${ }^{b}$ \\ ${ }^{a, b}$ Bucharest University of Economic Studies, Romania
}

DOI: $10.24818 / \mathrm{IMC} / 2020 / 02.17$

\begin{abstract}
Purpose: This article focuses on summarizing research on the relationship between investment in higher education and economic development in several East Asian countries, namely China and South Korea, whose characteristics and conditions are similar to Vietnam. The studies show that higher education plays an essential role in a country's economic development. For Vietnam, the studies also show that higher education is the driving force for economic growth; higher education contributes to income growth; higher education is a development factor. Therefore, this paper concludes: investment in higher education is an investment for economic development. At the same time, the article draws lessons learned from East Asian countries, which can be applied to Vietnam to increase the efficiency of higher education investment and promote economic development.

Design/ methodology/approach: literature review
\end{abstract}

KEYWORDS: economic development, higher education, investment, Vietnam

\section{INTRODUCTION}

In the era of the fourth industrial revolution, when intelligence has become a principal element of a nation's power and strength, countries around the world are aware that education is not only social welfare but also an essential lever for economic and social development. Education and economics show the following relationships: interdependence, mutual promotion, mutual impact, and mutual restraint. In particular, higher education becomes the driving force for economic development (Wang \& Gao, 2014 ). Developing countries that want to develop quickly must pay special attention to education and invest in higher education, which is also an investment in development. People armed with modern knowledge will be the primary driving force of socio-economic development.

In recent years, the Vietnamese government has paid much attention to the field of higher education, especially the promulgation of many policies to enable higher education institutions to improve their training quality and expand the training scale. Higher education institutions are continually innovating, increasing credibility, improving the content of the curriculum to increase the quality, and meeting the learning needs of the society; continually looking for opportunities to link with domestic and foreign partners to improve the quality and provide suitable human resources for society. However, many resources have not met the requirements of higher education institutions and need to be invested and improved increasingly.

The human element is one of the most critical factors contributing to economic growth. The economic development of a nation or a region is inseparable from human capital, while higher education is an essential factor in ensuring the quantity and quality of the human capital. In other words, higher education provides high-quality human resources for economic development. Conversely, economic development will also increase investment in higher education, thereby promoting the development of higher education (Wang, BR; Wang , ZG;, 2013). Thus, it can be said that investment in higher education is investment for economic development.

\footnotetext{
${ }^{*}$ Corresponding author. E-mail address:hoaitrinh.hce@gmail.com
} 
In the context of a developing economy, Vietnam's state budget for education is limited, and investment in higher education of people is low. Therefore, the requirement for higher education in Vietnam is to choose the right investment model, improve the quality of education, contribute to accelerating economic growth, and promote international economic integration.

This paper will present the reciprocal relationship between investment in higher education and economic development through an analysis of studies in several countries in East Asia. Thereby the author proposes some experiences that Vietnam can apply. The paper is organized as follows: the first part refers to a brief literature review of studies, the second part explains the methodology used by the authors in this article, and the third part includes results and discussion, while the final part concludes and proposes some solutions.

\section{LITERATURE REVIEW}

\subsection{Investment in higher education and economic development in some East Asian countries.} Investment in higher education is a concept used in economics, on the understanding that investment in higher education is represented by spending on education in colleges and universities (Shuang Lu, 2018).

\section{The role of higher education in economic development}

With the development of the knowledge economy, education has become an essence from the periphery of the economic society, and thus higher education has gradually become "the incubator" of technology and "the driving force" of economic development. Education and the economy interact and support each another, thus promoting the development and progress of society (Chen , 2007). It can be seen that the financial investment in higher education has a significant influence on the development of the economy (Luo \& Zheng, 2011).

Some studies look at the role of human capital in economic growth on a national scale including provinces, cities, or different localities in a country. Such studies are concentrated mainly in China, where there are provinces/cities with significantly different growth rates - a trait considered to be similar to Vietnam. For example, some authors (Zhang \& Zhuang , 2011) considered the impact of human capital on economic growth at the provincial / city level of China. Results show that higher education plays a more critical role than primary and lower secondary education. Moreover, the evidence suggests that the role of human capital components in regional economic growth is related to the level of development. The more developed provinces benefit more from higher education, while underdeveloped provinces rely heavily on primary and lower secondary education. Some authors (Ding \& Knight, 2011) studied over 30 provinces in China and found that accumulating human capital (both physical capital) would stimulate economic growth. However, physical capital investment contributes to growth only when it is strongly associated with the advancement in technology. Moreover, the results also show that the enrollment rate from lower secondary school onwards has an impact on economic growth, with an emphasis on higher education while primary education does not have any effect on the growth. In one study (Su \& Liu, 2016) considered the impact of human capital along with foreign direct investment on the economic growth of major cities in China during 1991-2000. The two authors found that human capital had a positive effect on economic growth. Human capital also helps to diffuse the technology that comes with foreign direct investment. Some authors (Li \& Wang, 2016) also found that human capital would influence the growth of provinces/cities in China. In particular, human capital is divided into Basic Human Capital and Advanced Human Capital. Basic human capital is the proportion involved in basic education, including primary, lower, high, and professional secondary schools, while Advanced human capital is the participation rate after high school. Basic human capital contributes to economic growth through the Factor-accumulation channel and human capital from higher education influences growth through the Productivity channel.

Regarding the relationship between education and economic development for one of the most important economies in the world (Chinese economy), there is long-term cooperation between these 
two variables. After long-term analyses, it was found that when financial investment in higher education increased by $1 \%$, economic growth would increase by $0.915 \%$ (Qiang , 2018). Obviously, financial investment in higher education has a significant influence on the development of the economy (Luo \& Zheng, 2011) and this study also draw on the role of higher education investment in economic development, which says education is the driving force of the economy, the fulcrum for economic development and transformation. At the same time, higher education, taking the dissemination, conservation, and innovation of information knowledge as the main task, plays a more critical role in the development of economic activities. With the rapid development of higher education, there has been a wave of construction investment in higher education in the country, not only to improve leadership in the process of higher education development but also to promote economic growth. Through a model for improving economic growth, there is an empirical analysis of the contribution of investment in higher education to China's economic growth. The results show that in the period 1980-2008, the ratio of investment in capital construction was higher than China's education for the economic growth of 3.05\%, and its elasticity was only 0.03 . Alternatively, as in other study (Shuang , Xiaoxia, \& Yi, 2018), the author used the Cobb Douglas production function through Barro expansion in three provinces of China. With a regression analysis from 1999 to 2016, the results show that for every 1-percent increase in educational expenditures of ordinary colleges and universities in Beijing, the region's GDP will increase by 0.332 percent. For every 1-percent increase in education expenditures for ordinary colleges and universities in Tianjin, the region's GDP will increase by 0.252 percent. For every 1-percent increase in educational expenditures of regular colleges and universities in Hebei, the region's GDP will increase by 0.251 percent. Therefore, capital construction investment in higher education has little effect on China's economic growth, and is not a way to promote significant economic growth (Luo \& Zheng, 2011). Similarly, in Korea, in one study (Kang, 2006) has argued that the "miracle of economic growth" does not occur in Korea, due to diminishing returns on the scale of technology and the growth is mostly based on the rapid rate of capital accumulation. Another very interesting study (Permani, 2009) presented education as an intermediary - complement and support for other growth factors such as transparency (Kwack \& Lee, 2006); physical capital (Pyo, 1995); exports (Kang, 2006) without having to go directly through judgment of (Lee, 2000).

\subsection{Investment in higher education and economic development in Vietnam The impact of higher education to economic development}

In Vietnam, there have been some empirical studies on the role of higher education in growth in recent years and also many efforts to measure the real yield of investment in education in general and higher education in particular. Some authors (Klump; Bonschab; 2004) tried to explain Vietnam's growth experienced in recent years, based on socioeconomic variables, including human capital (Dat, Factors affecting the economic growth of Vietnam's provinces and cities in the 2000-2006 period and some recommendations for the coming period, 2008). In other study (Anh \& Ba, 2005) built a neoclassical model for Vietnam based on the Cobb - Douglas production function expanded for human capital, which stated that: Human capital and labor are the primary sources contributing to the creation of added value, while the contribution of technological progress and management capacity is low. Another interesting study (Dat, Factors affecting the economic growth of Vietnam's provinces and cities in the 2000-2006 period and some recommendations for the coming period, 2008) used the smallest square dummy variable model and expanded Cobb - Douglas production function to assess the role of human capital in the economic growth of provinces and cities in Vietnam during 20002007. In a study on East Asian growth (Permani, 2009) mentioned another study (Kikuchi, 2007) which using data from the 1998 household living standard survey, the author has found that education is one of the important determinants of income in Vietnam. In other study (Dat , Economic growth during the renovation period in Vietnam, 2011), the impact of education on the economic growth of provinces/cities in Vietnam has been considered through the measure of the education level of the labor force, which is the "average number of years of schooling." 
The regression results show that the "average number of years of schooling" of the labor force has a positive impact on GDP and GDP / labor. The estimated coefficient varies from 0.10 to 0.14 for GDP or 0.10 to 0.16 for GDP / labor implies that: If all other factors remain unchanged, a $1 \%$ increase in the average number of years of

schooling will increase GDP by 0.10 to $0.14 \%$ per year or GDP / labor by 0.10 to $0.16 \%$ per year. In Vietnam, the average education level of the labor force in most provinces varied from 5 to 9 years in the period 2000-2006. Therefore, when the "average number of years of schooling" increases by one year, the country's income can increase estimated by $1.5-2.7 \%$ / year.

In one very interesting study (Nguyet, Ly, \& Thao, 2018) conducted a study from 2000 to 2016 of 63 provinces/cities in Vietnam, finding that the proportion of employees with university or higher level of education no longer shows a statistical impact on economic growth. At the same time, the proportion of employees with upper secondary education is statistically significant in the individual regressions as well as in regression concurrently with the rates of labor at other levels. The average number of years of schooling becomes statistically significant. This statement reflects precisely the reality of Vietnam; Vietnam's economic growth still depends heavily on unskilled labor; high-level education has not played a leading role in economic growth. Another remarkable result is that spending on education also becomes less statistically significant in the System Generalized Method of Moments (SGMM) estimation. This result reveals that impact of higher education was not clearly shown on economic growth.

Thus, the research results drawn on the impact of education on economic growth in Vietnam are entirely consistent with some other studies in East Asia.

\section{RESEARCH METHODOLOGY}

The method predominantly used in this paper is the examination of the scientific literature for the purpose of creating comprehensive reviews and identifying the significant aspects of related studies. Besides, the author simultaneously used descriptive statistics tools based on the published data that is relevant to each mentioned aspect.

Specifically, the progress of examining scientific literature was based on the studies that mentioned the relationship between higher education and economic growth. By calculating the published data and using descriptive statistics tools, the author will evaluate this relationship more accurately.

1. The search and identification of the primary documents related to the topic.

The author searches for documents from the database of Web of Science, Scopus, Google scholar, etc. Because the subject is relatively broad, the author focuses on research with areas whose political or economic characteristics are similar to Vietnam. Also, the author searched for the published data that is relevant by using the keywords "investment in higher education, "economic development," "China," "Korea," "GDP," etc.

2. Identification and analysis of the searched scientific literature that will be the object of analysis. With the searched documents and data, the author will classify the papers by the significant aspect in each country. Subsequently, the classified paper will be the subject of the analysis. Also, the data will be calculated in order to create statistics for each country it relevant.

\section{RESULTS AND DISCUSSIONS}

\subsection{The situation of educational investment in East Asia 4.1.1. Invest according to state budget}

Since the 1980s, the South Korea Government started to make strategic investments in human resource development, research, and technological innovation. Korean households also spend many resources on education, thereby vigorously promoting investment in this field (Deepti, 2018).

In 2016, China's GDP was 11.14 trillion USD; The government spent 445.6 billion USD, which accounted for $4 \%$ of GDP, on education in general, including higher education. This is a significant 
number. Korea spent $4.6 \%$ of GDP, and Vietnam spent $4.3 \%$ of GDP on education. This number demonstrates that all three countries invest heavily in education, and the government is very concerned about human development. However, when looking at higher education expenditure, due to limited data collection in Korea and China, the author only commented on Vietnam in this regard. With limited budgets, 4.3\% of GDP is a large number for the government's investment in education. However, Vietnam's expenditure on higher education accounted for only $0.5 \%-1 \%$ of GDP (Trinh \& Cicea, 2019). As such, Vietnamese education lacks investment in higher education, although higher education plays a vital role in the economy, because it is responsible for well-trained human resources, with high performance (productivity) in companies (Naroș \& Simionescu, 2019).

Table 1. Percentage of GDP and budget for education in 2016

\begin{tabular}{|c|c|c|}
\hline Country & $\begin{array}{c}\text { Budget for education (billion } \\
\text { USD) }\end{array}$ & Percentage of GDP (\%) \\
\hline China & 445.6 & 4.0 \\
\hline South Korea & 65 & 4.6 \\
\hline Vietnam & 8,8275 & 4.3 \\
\hline
\end{tabular}

Source: https://data.worldbank.org/indicator/SE.XPD.TOTL.GD.ZS?most_recent_value_desc=true

\subsubsection{Universities tuition fee}

In Korea, when families have good economic conditions, parents are willing to share the cost with the state through paying their children's tuition. This form of investment is suitable for developed countries. It would provide a quality environment for children of families with economic conditions. Also, it has helped Korea to mobilize a lot of financial resources from the tuition paid by the parents (Vietnam Academy of Science and Education, 2016).

The author analyzes data of these countries' university tuition fees from two universities with good training quality and a high rate of enrollment (including international students). With four years of study, the amount of tuition to pay at Seoul and Chungnam University is not high and relatively suitable for domestic students and international students who want to study at these schools. However, for China, four years of schooling does not include living expenses, the cost of studying at the school is too high, twice as much as that in Korea and six times higher than that in Vietnam. According to the country's Ministry of Education, China now has 2,688 public universities with more than 40 million students. The total investment budget for education in 2019 was more than 713 billion USD, increased by $8.74 \%$ compared to 2018. In particular, investment in tertiary education is 192 billion USD, an increase of nearly $12 \%$ compared to 2018 . However, this budget seems like a drop in the bucket, and parents still have to bear significant expenses when sending their children to college.

Table 2. Tuition fees in some countries

\begin{tabular}{|c|c|c|c|}
\hline Country & Name of University & $\begin{array}{c}\text { Tuition fee (for 4 } \\
\text { years) }\end{array}$ & Year \\
\hline \multirow{2}{*}{ South Korea } & Seoul National University & 8164 USD & $2015-2019$ \\
\cline { 2 - 4 } & Chungnam National University & 5541 USD & $2015-2019$ \\
\hline \multirow{2}{*}{ China } & Peking University & 15680 USD & $2015-2019$ \\
\cline { 2 - 4 } & Shanghai Jiaotong University & 13888 USD & $2015-2019$ \\
\hline \multirow{2}{*}{ Vietnam } & Hanoi Law University & 2572 USD & $2015-2019$ \\
\cline { 2 - 4 } & $\begin{array}{c}\text { Ho Chi Minh City Medicine and } \\
\text { Pharmacy University }\end{array}$ & 3852 USD & $2015-2019$ \\
\hline
\end{tabular}

Source:https://www.gotouniversity.com/compare-universities/tuition-fee/seoul-national-university- 
Apparently, graduating from prestigious universities in Korea and China will increase employment opportunities, and top university graduates often hold managerial and senior positions in the nation's major economic corporations (OECD, OECD Reviews of Tertiary Education, 2009).

In Vietnam, in the context of economic growth, the state budget is still limited; the cost shared by households with the state will not be high. During the four years of university, the average household pays 2000-4000 USD, which is drastically low compared to the region.

\subsubsection{Investment for development}

In this era of development, R\&D is an activity that brings more economic benefits than other activities. Some author (Szarowska, 2016) confirms the positive and statistically significant impact of government R\&D spending, which is the main driving force for economic growth during the analyzed period. Thus, it can be said that spending on higher education R\&D is of high importance and has a positive impact in the post-crisis period.

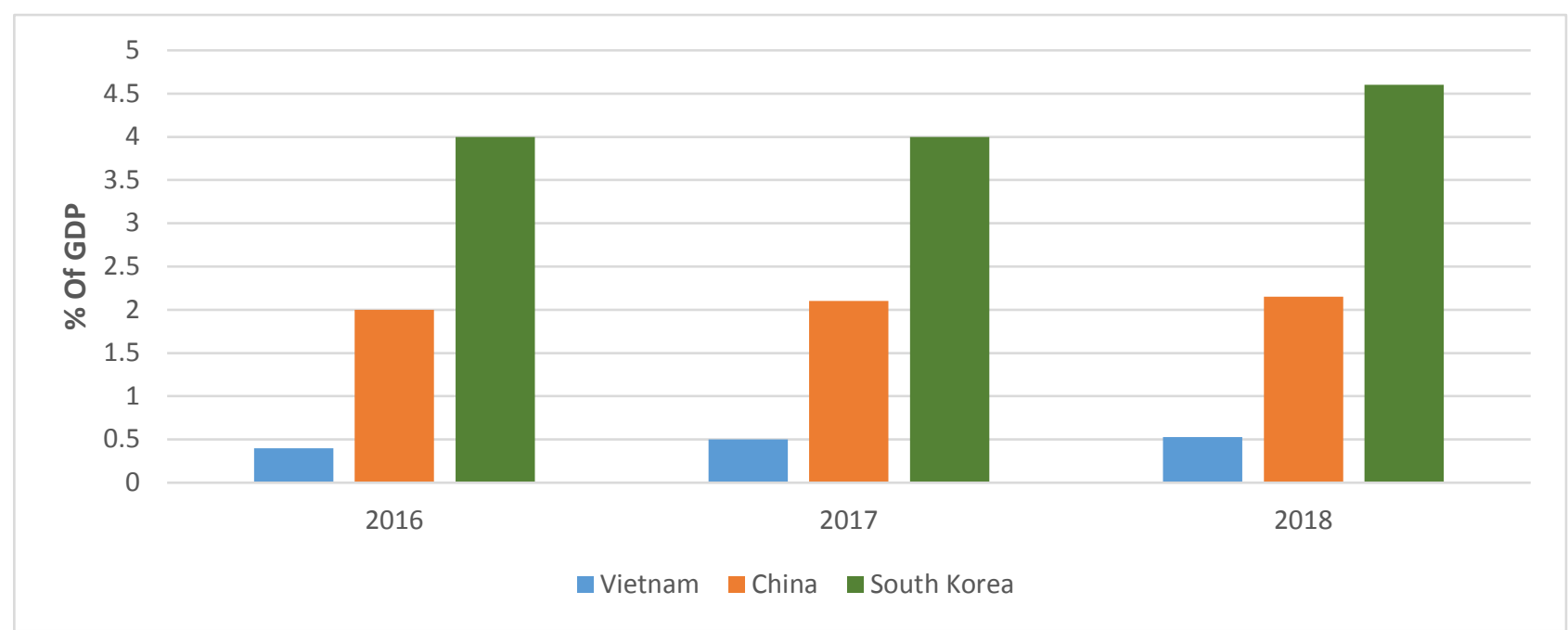

Figure 1: Research and Development Expenditure (\% Of GDP)

Source: tradingeconomics.com

R\&D spending in China is always high, equivalent to the budget expenditure for education. It can be understood that China's human resource development and R\&D are always attached with investment and development in parallel with the investment rate of $4.6 \%$ compared to GDP. This was followed by South Korea with an investment of $2.1 \%$ of GDP and finally Vietnam with only $0.5 \%$ of GDP.

For a country with an ambition for economic development, R\&D spending in that country is relatively appropriate; only Vietnam is too low. This situation is easy to understand because the state budget is limited, and the complicated legal corridor limits the policy to attract investment so that the budget distribution will be limited for each item.

\subsubsection{Higher education investment policy}

In a very interesting study (Jung , 2011) presented that Korea has established a long-term plan with economic development as the primary focus. This policy was continued by President Park from 1961 to 1979 and by subsequent governments, emphasizing the development of human resources to stimulate economic development. During this period, national policies focused on economic development, and policies for other sectors were considered complementary to economic development (Rha \& Byun, 2007). For example, it is believed that workers' rights, freedom of speech, and academic freedom can be sacrificed to support economic development. Education is not considered independent of economic development, but rather a system of support through the creation of trained and educated human resources which is similar to other Asian countries where economic development is a top priority (Wang \& Liu, 2010). This statement can be understood by considering the relevance of industrial development and educational development over the past four decades 
(Choi, 1997). Higher education has become important since technology-based industries emerged in the 1980s and 1990s, and postgraduate education has become so since knowledge-based economies emerged in the late 1990s.

In the 1990s, with the shift to a global economy, the South Korea government began to shift its industrial focus to the high-tech industry. The South Korea government began to emphasize research productivity in its resource allocation to stimulate knowledge production and knowledge-based innovation. There are many investment policies in Korea for higher education. However, the "Brain Korea 21" project (BK 21) is a major higher education reform project. This project aims to cultivate the innovative and high-quality human resources necessary for a knowledge-based society. The government has invested 1.4 trillion won (about US \$ 1.2 billion) in universities over seven years. Three-quarters of the budget would be invested to support graduate schools in certain areas of natural and applied sciences, humanities, and social sciences. At the same time, selected universities will be developed into the world's top universities. The remaining organizations will become regional universities that will create the human resources required by local industries. Graduates in selected graduate schools are direct beneficiaries of the project. Research funds do not go directly to professors in the form of grants, and a large portion of the budget is used to provide a supportive educational environment for postgraduate students in the form of grants and financial aid for overseas research and research infrastructure (Mugyeong \& Ki-Seok, 2001).

Regarding Higher education in China, some authors (Neave \& Van Vught, 1994) is operated under the model of state control and controlled state model.

In other study (Mei \& Yang, 2014), resource allocation, administrative control, use of teaching and research staff, curriculum development, textbook selection, student recruitment and job placement for graduates, are the sole responsibilities of the central government. This study also added that, in 1985, the Chinese government reformed higher education, and the Chinese government stated that university autonomy was highly significant.

As a result, many changes have been made to reduce central government control over higher education in China to allow autonomy within the university.

In another study (Guo, 1995) asserted that autonomy in Chinese universities at that time allowed them to initiate a policy of coordinating with industries to meet economic and social needs.

Efforts to ensure freedom in higher education in China continued in 1993 to reaffirm the decision in 1985.

China's education reform and development program have caused the central government to exercise direct control over education, especially higher education.

Some authors (Mei \& Yang, 2014) mentioned that: The Higher Education Law gives higher education institutions the freedom to conduct scientific research and any academic activities at the school level. The rapid growth of Chinese higher education can be attributed to its financial policy model.

Financing Chinese higher education before the opening policy was the monopolized centralized financial system, or in other words, financing higher education was the sole responsibility of the central government.

From 1993 to now, based on government financing and multi-channel funding, the higher education funding system has changed into a cost-sharing method where higher education costs are shared between government and beneficiaries.

According to a very interesting study (Wenli \& Qiang , 2013), since 1989, most universities in China have adopted the fee policy, collecting about 14-43 USD as tuition fee/student per academic year.

In the early 1990s, with the improvement of the public's ability to pay, the government gradually increased the tuition fees for higher education. And to this day, the Chinese government has increased its investment in university education. This led to an educational system adaptive to the socialist market economy, with the government being the primary source of funding, and the budget is raised from taxes for education, tuition, and donations to supplement efforts of the government.

Also, China focuses on investing in a few vital research universities that are internationally competitive. Most of them are institutions that belong to a limited group of top Chinese universities, having received billions of dollars in funding from two well-known projects, 985 and 211 (Philip, 
2009). The purpose of the two projects mentioned above is to improve the quality of higher education, focus on technological innovation, facilitate innovative talents, and leverage adaptability so that China's top universities become an essential driving force for the creation of an innovative nation (Hung, et al., 2010).

\section{ECONOMIC DEVELOPMENT IN EAST ASIA}

\subsection{The income of employees}

Looking at figure 2, we see that the average income per capita of China and Korea has exceeded the threshold of USD 30,000. This number proves that, in terms of economic power, the two countries have officially entered the ranks of developed countries in the world, which is the "30-50 club" -only countries with more than 50 million people and a per capita income of over USD 30,000. Secondly, the average income reached over USD 30,000 shows that the country has overcome the "middleincome trap". "Middle-income trap" is a situation in which a country succeeds in moving from a developing country to a middle-income country, but only remains that income level and could not cross the threshold to become a richer country.

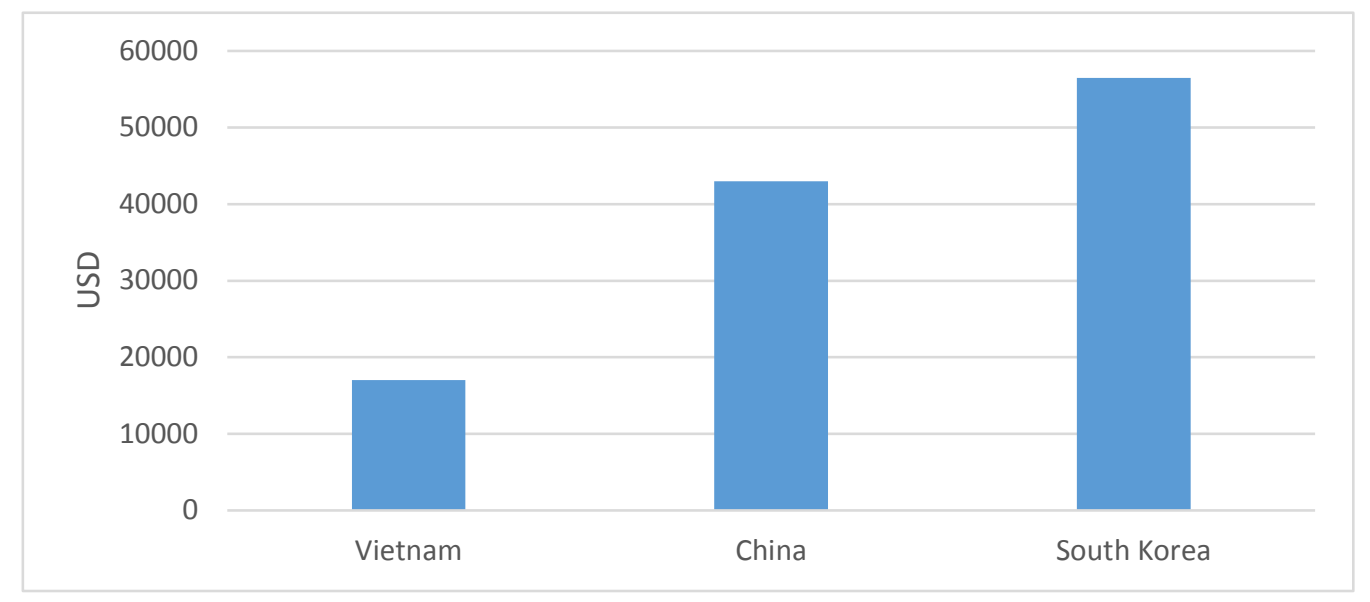

Figure 2: Annual average wage of Bachelor degree in 2019 Source: www.averagesalarysurvey.com

Coming back to the investment policies of Korea and China, compared to chart 2, the author argues that it is because of reasonable reform and investment policy and projects focusing on human capital, both Korea and China have trained high-quality human resources that have an impact on income and lift themselves out of the "middle income trap".

Vietnam began to "innovate" in 1986, and this reform has turned Vietnam from the group of the world's poorest countries into one of the most famous success stories. Despite the unprecedented success, Vietnam's development journey has not yet completed. The per capita income of Vietnamese people is currently 17,000 USD, only equal to $40 \%$ of the global average, $20 \%$ of the average of the Association of Southeast Asian Nations (ASEAN), and 5\% of the average of high-income economies. It will take Vietnam about 30 years to achieve China's current gross domestic product (GDP) per capita and ten years to achieve South Korea.

\subsection{Economic growth}

Figure 3 shows that in 2010 Vietnam's economic growth rate was 3.5\% lower than China's growth rate and $0.5 \%$ higher than South Korea. Then by 2015, the economic growth rate was close to China's growth rate of 7\%, while Korea only increased slightly by 2.5\%. From 2016 to 2018, Vietnam's economic growth rate increased faster than China and South Korea. In 2018, Vietnam's economic growth rate increased faster than China for the first time. This number shows that the transformation of Vietnam's economic growth model is appropriate and effective. Due to the fast and stable economic 
growth, GDP per capita increased continuously over the years: 1,571 USD in 2011; 2109 USD in 2015; and in 2018 it reached 2,587 USD - 1.65 times higher than in 2011. The GDP growth rate per person in the 2011-2018 period reached 9.41\% / year, higher than the 9.26\%/year of the 2001-2010 period (Ha, 2020).

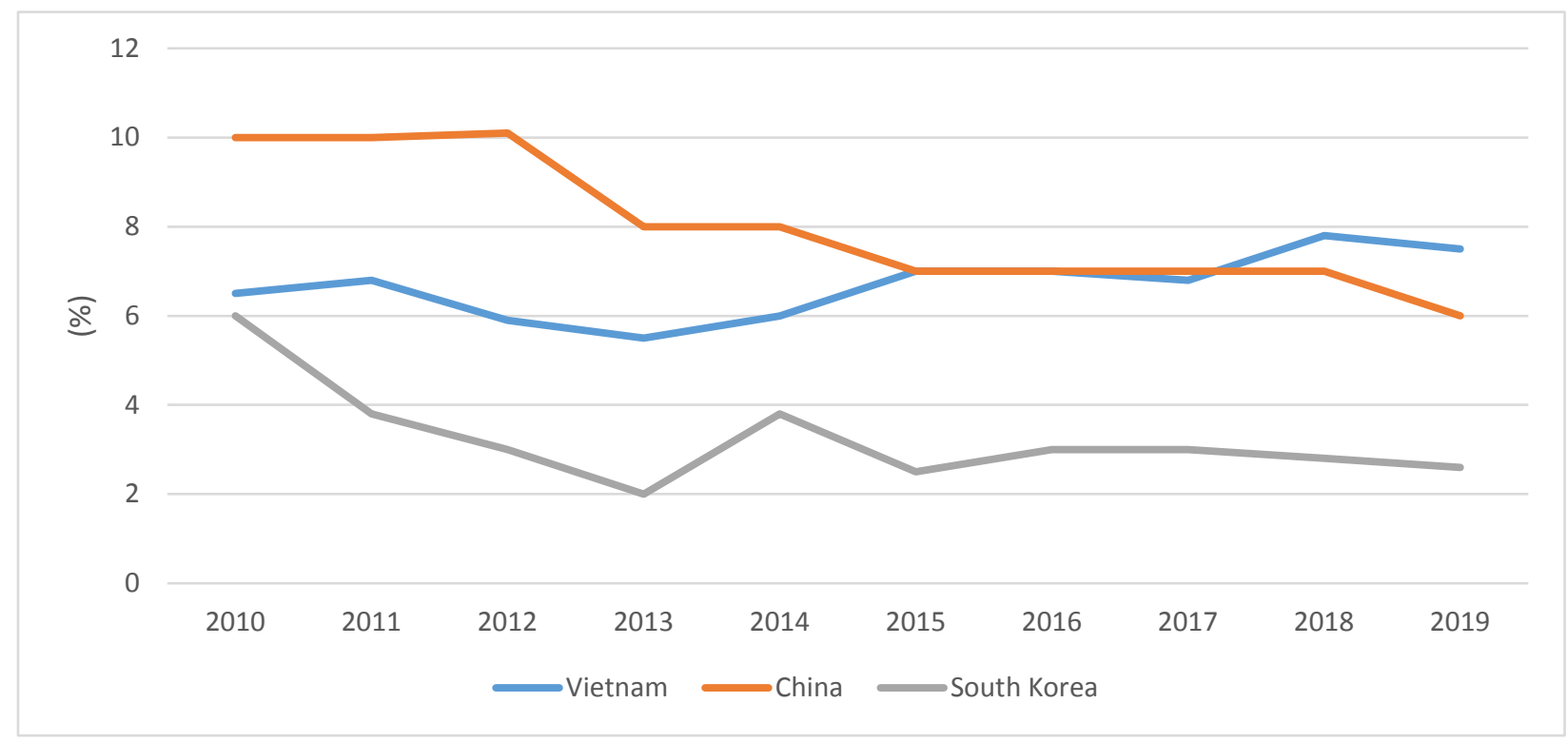

Figure 3: GDP Annual growth rate

Source: tradingeconomics.com

Vietnam's GDP growth in 2019 reached 7.5\%; Although the growth rate in 2019 was lower than the rate of 7.8\% in 2018, it was higher than the rates during the period 2011-2017. Meanwhile, the GDP growth of China and South Korea tended to decrease. It can be said that 2019 is the year when China's economy is at its lowest level, and Korea has the slowest growth rate during the period of 2010-2019. The main reason for the aforementioned low growth rate is the US-China trade war and the slow recovery in the global semiconductor market (Bank of Korea, 2019).

Thus, in terms of investment situation and economic growth, the author concludes that: Investment in higher education is not a direct determinant of economic growth. Human resources from higher education are not those that directly affect the economic development of countries. This statement is entirely consistent with the research of (Luo \& Zheng, 2011); (Permani, 2009); (Nguyet, Ly, \& Thao, 2018).

On the other hand, the growth rate is slow, but the income per capita of Korea and that of China are very high, which reflects the two-way impact of a country's economic development on its income. At the same time, increasing incomes will lead to GDP growth.

Regarding Vietnam, the main labor force is still unskilled labor, and the work efficiency is not high. Meanwhile, human resources through university training have yet to be utilized as the leader of economic growth, lacking in flexibility and creativity, and eventually leading to low incomes.

\section{BILATERAL CONNECTION BETWEEN EDUCATIONAL INVESTMENT AND ECONOMIC DEVELOPMENT IN EAST ASIA}

Like many other regions, the author finds a meaningful two-way causal relationship between investment in higher education and economic development in East Asian countries. In the above section (the situation of educational investment in East Asia), as the author presents: countries like Korea and China have heavily invested in higher education with 4 to $4.6 \%$ of their GDP, which is not a small number for the GDPs of these countries. Besides, to keep up with the trends, the governments have also spent a lot on R\&D. Moreover, when economic growth is high, income increases, thus households in these countries are willing to share costs with the government through the payment of 
tuition fees for their children, while university tuitions in these countries are very high compared to the East Asian region. This phenomenon proves that the economic development of a country will motivate that country to return to investments in its human resources. There is no doubt that these countries have such a young generation with qualified, dynamic, and highly competitive human resources with the world.

In another aspect, higher education provides high-quality human resources for economic development, increasing the demand for qualified labor and resulting in a considerable increase in the number of people participating in higher education, which leads to increasing competitiveness of qualified workers and thus allows for higher income and economic growth (Zin, 2005). Figure 2 and figure 3 reflect this statement clearly. In the digital age, a country that wants to develop and have a high income cannot rely on unskilled labor, but the main force must be intellectual labor through university training. Korea and China have escaped the "middle-income trap" and have a very high GDP compared to other countries in the region. This reality proves that investment in higher education is, indeed, an investment in economic development. Despite the current situation, higher education has not realized its potential as the key player in promoting these countries' economic development.

Regarding Vietnam, the main labor force is still unskilled labor, and the work efficiency is not high. Meanwhile, human resources through university training have yet to be utilized as the leader of economic growth, lacking in flexibility and creativity, and eventually leading to low incomes.

Therefore, it can be affirmed that in developed countries, investment in higher education and economic development has a bilateral relationship, interacting with each other.

\section{CONCLUSION}

From the analysis above, the author affirms the bilateral relationship of investment in higher education and economic development. Although higher education is not the main factor in promoting economic development, it is undeniable that higher education is an essential factor contributing to countries' economic development. This statement is reflected in the results achieved by the government's investment in higher education as follows:

According to the (OECD, Population with tertiary education (indicator), 2017), 70\% of Koreans aged 24-35 have completed higher education, which is the highest rate in the world. South Korea has a topquality school system that can be measured by student achievement in some standardized tests. Korea has always been ranked among the best-performing countries in the International Student Assessment Program (PISA).

Seoul National University has always been considered as one of Asia's leading universities (ranked 13) and in the world (ranked 124, according to the rankings of THES). Many other universities such as Chungnam, Chonbuk, Chonnam, Pusan, Sogang, Inha, etc. have also become respectable names in the region and the world. South Korea universities, whether public and private, have attracted many international students, including Vietnamese, to attend.

Higher education development leads to the development of science and technology. Currently, the number of full-time researchers in South Korea is 236,000. This figure is higher than that of France (211,000), England (175,000), but lower than Germany $(284,000)$.

Korea also has some large and highly reputable research centers. The Korea Advanced Institute of Science and Technology (KAIST) - a model that Japan has based on to create the Japan Advanced Institute of Science and Technology (JAIST) - is a well-known research center in the world.

In terms of the number of scientific publications in international journals, South Korea has leaped forward as well as China. In 1990, the total number of scientific articles from Korea on international scientific journals was only 1382 articles (which approximates to the current figure of Vietnam). However, by 2008, this number reached 26690 articles, with an increase of 20 times in less than 20 years.

South Korea's most researched fields (through the number of scientific publications) are biomedical (accounting for $35 \%$ of the total number of scientific publications), natural sciences (37\%), and 
engineering (26\%). The number of patents registered abroad (mainly the US, Europe, and Japan) increased from 1,382 in 2002 to 3,158 in 2005. The number of patents registered in the country increased from 45,298 in 2002 to 123,705 in 2007.

Of course, educational and scientific development and economic growth interact with one another. Economic growth creates a labor market for university students and provides income for the state to invest in higher education. Higher education then provides high-quality human resources for economic development.

Quality of education. Because of the rapid growth of higher education, the South Korea Government places great emphasis on quality. They use three means to control quality.

The first is the development of standards for university accreditation and curriculum accreditation. Secondly, they use the indicators of achievements in training and scientific research to determine the amount of funding for universities. Thirdly, the government and the technology industry invest in scientific research and use scientific research as a performance indicator to provide a budget for universities. This strategy is reflected in Korea's 4.6\% of GDP spent on research and development, and this proportion is among the highest among OECD countries. In term of China which has the lowest dropout rate in the world, their universities have less than $1 \%$ of students not completing the degree. Although higher education in East Asia is generally characterized by high entry requirements and low dropout rates, this rate in Korea and Japan is still around 10\% - a far cry from the situation in China. The average graduation rate for four years of schooling in 2013 was $97.3 \%$. The percentage of bachelor's degrees is $96 \%$, lower than the graduation rate. Typically, the Graduate Certificate only requires all subjects to have a passing score, plus a specified number of certificates, while a bachelor's degree may require a certain GPA. The quality and ranking of a university do not seem to make a difference. The national key universities in "Project 211" have higher entry requirements than those in smaller provinces, but the graduation rate is lower than the average by less than $0.5 \%$. It seems that geographical location is what makes a small difference in graduation rates; In Hebei, where most of the colleges have been upgraded to a university in recent years - the average university graduation rate is $98.8 \%$, while in Shanghai, the percentage dropped to 95.9\%. In some universities, faculties operate in collaboration with foreign partner organizations, which tend to be challenging to graduates, and they have an average graduation rate of just over 90\% (Marioulas, 2017).

Besides the achieved results, there are still some limitations as follows:

First of all, China is developing an unbalanced education. While top universities are generously funded, and many are now able to compete with the world's best universities, this does not happen with smaller universities, applied universities (polytechnics), or colleges that have been receiving large numbers of students from the entire system over the past two decades (China now has the largest student population in the world). The majority of public universities are in the "demand-driven" group, and an increasing number of private universities at the bottom of the system is not adequately invested and of low quality. Many people have criticized the situation, stating that many graduates from these schools are not well-prepared to enter the labor market, thus not getting jobs. Also, lecturers at Chinese universities do not get academic freedom (Marioulas, 2017).

Secondly, both Korea and China attach great importance to public education. This unintentionally creates fierce competition when students take entrance exams, and as a result, "higher education is distorted in unexpected ways" (Hyunsu, 2018).

Thirdly, the efficiency of investment in higher education in Korea and China is not high. The research results show that the labor force from higher education training in the two countries is not the main factor directly driving economic growth, while both the Korean and Chinese governments spend heavily on higher education.

From the achievements of the countries mentioned above as well as the limitations that Korea and China still exist, Vietnam can draw lessons for investment in education and economic development as follows:

First, regarding the management of the state, the State should have policies to support, promote, and ensure academic freedom as the core value of university autonomy. Besides, universities need to research and develop mechanisms themselves to allow and encourage academic freedom as an aspect 
of university autonomy to promote the internal strength of faculty members. Next, the State needs to develop a sound legal framework for university autonomy and academic freedom. The development of a legal framework for university autonomy and academic freedom should be geared towards equality between faculty members of public and private universities.

Vietnam can learn from a strategy of combining strict management autonomy and accountability. Universities are allowed to make decisions about management without State intervention, for example: selecting curricula from abroad, designing training programs, setting up faculties, recruiting domestic and foreign lecturers, modernizing research and teaching equipment, etc..., in order to achieve the quality standards set by the State.

In addition, universities must report responsibly to the State on ongoing issues to ensure that these activities are still aligned with the university's educational goals and vision of the country. It also helps to protect schools from administrative interference.

Secondly, regarding building elite universities, China has been determined to build some excellent research universities for the purpose of international integration and proving the national status. South Korea has chosen Seoul University as the high-quality university to be an icon for Korea. Therefore, the Vietnamese government and educational institutions should select key schools, invest with the budgets, and set appropriate admission criteria to build universities in two models: research university and applied university.

Thirdly, regarding the state resource allocation, China and South Korea have changed the criteria for allocating state budget to universities from the number of previous enrollment students to the number of research grants and the number of patents that the school has been granted; or scientific publications of lecturers in peer-reviewed international scientific journals. This policy creates transparency and pressure for universities to improve the quality and evaluate lecturers more objectively.

The Vietnamese government should call for funding to share costs with the government and households because, for a developing country where there is still a poverty rate, university autonomy and household cost-sharing will inevitably differentiate between the rich and poor among students, because the beneficiaries of higher education have the right to choose a higher education institution appropriate to their capacity, but not every family can afford a tuition fee.

The Vietnamese government should increase spending on research and development. South Korea and China are clear evidence that high-quality and innovative human resources will help promote a nation's position in the process of economic development.

Vietnam's higher education should train students in ways that accommodate to the needs of society, minimizing unemployment after graduation.

This article still has some limitations. First of all, the authors only considered several contents related to the topic and analyzed some typical scientific studies accessed from major databases such as Web of Science, Scopus, and the figures collected from related ministries' reports. Simultaneously, not every research directions and aspects are mentioned in this article due to the authors' limited access data.

Secondly, East Asia is a vast region; in order to facilitate the research direction of the article, the author only focuses on three countries with relatively similar political and economic situations. Therefore, there are still many aspects in other East Asia countries that the author has not fully exploited.

Based on the above limitations, the authors can determine the direction to carry out an in-depth analysis of the articles' content in the future. 


\section{REFERENCES}

Anh, N., \& Ba, L. (2005). Quality of economic growth: some initial assessments for Vietnam.

Bank of Korea. (2019, 3 29). 2018 Annual Report. Retrieved June 30, 2020, from https://www.bok.or.kr/eng/bbs/E0000740/view.do?nttId=10052517\&menuNo=400221\&fbclid =IwAR3NeCFwPtVq4F8f9W8un7LXW4Iedju0O_0GT2baKxZELIPMq96B24jjtK8

Chen , Y. (2007). An empirical research on the contribution rate of higher education in central China to its economic development. I and II. PROCEEDINGS OF THE 4TH INTERNATIONAL CONFERENCE ON INNOVATION \& MANAGEMENT.

Choi, K. (1997). The contribution of investment in education to economic growth in Korea. The Journal of Economics and Finance of Education (in Korean), 6(1), 229-257.

Dat , T. T. (2011). Economic growth during the renovation period in Vietnam. Hanoi: Publisher of National Economics University.

Dat, T. T. (2008). Factors affecting the economic growth of Vietnam's provinces and cities in the 2000-2006 period and some recommendations for the coming period.

Deepti, M. (2018). World Education News + Reviews. Retrieved June 30, 2020, from https://wenr.wes.org/2018/10/education-in-southkorea?fbclid=IwAR3BtHHcMKmlhsJ_WO_fv-5g7e3sWdnAN3FYW7gsMP2DPqobPvGv_Is0bk

Ding, S., \& Knight, J. (2011). Why has China grown so fast? The role of physical and human capital formation. Oxford Bulletin of Economics and Statistics, 141-174.

Guo, Q. (1995). A collection of education laws in the People's Republic of China. Beijing Broadcasting Institute Press.

Ha, B. (2020). Quality of Vietnam's economic growth in the period of 2011 - 2018. Vietnam Journal of Financial Economics.

Hung, T. B., Minh, K. C., Ha, D. B., Quan , N. M., Anh, N. P., \& Tien, P. A. (2010). Chinese strategies and policies to promote higher education innovation and training skilled workers.

Hyunsu, H. (2018). Behind the Scores; Myths on Korean education. Retrieved June 30, 2020, from https:/www.worldsofeducation.org/en/woe_homepage/woe_detail/15740/wdr2018-realitycheck-18-\%E2\%80\%9Cbehind-the-scores-myths-on-korean-education\%E2\%80\%9D-byhyunsu-hwang?fbclid=IwAR2Rr7--

fAwJtJvJz9bfxvykllrTsh2wczak8TO6w38CxUwT2QYGIZg9aUs

Jung , S. C. (2011). Higher education development in Korea: western university ideas, Confucian tradition, and economic development. Higher education 64(1), 59-72.

Kang, J. (2006). An estimation of growth model for South Korea using human capital. Journal of Asian Economics 17(5), 852-866.

Kikuchi, T. (2007). An analysis of the impacts of developmenton Gini inequality using grouped and invidual observations: examples from 1998 Vietnamese Household Expenditure Data. Journal of Asian Economics, 18(3), 537-553.

Klump, T. \& Bonschab, R. (2004). Operationalizing pro-poor growth- The Vietnam case study.

Kwack, S., \& Lee, Y. (2006). Analyzing the Korea's growth experience: the application of R\&D and human capital based growth models with demography. Journal of Asian Economics, 17(5), 818-831.

Lee, N. (2000). Education and ecnonomic growth in Korea, 1966 to 1997. Journal of applied Bussiness Research, 16(4), 83-83.

Li, T., \& Wang, Y. (2016). Growth channels of human capital: A Chinese panel data study. China Economic Review, 51(C), 309-322.

Luo, X., \& Zheng, K. (2011). The Contribution Research of Capital Construction Investment in Higher Education to the China Economy Growth. 1-6. NTERNATIONAL CONFERENCE ON ENGINEERING AND BUSINESS MANAGEMENT (EBM2011). 
Marioulas, J. (2017). China: A World Leader in Graduation Rates. International Higher Education, 28-29.

Mei, \& Yang. (2014). Governance reforms in higher education: A study of China. International Institute for Educational Planning.

Mugyeong, M., \& Ki-Seok, K. (2001). A Case of Korean Higher Education Reform: The Brain Korea 21 Project. Asia Pacific Education Review, 2, 96-105.

Naroș, M.-S., \& Simionescu, M. (2019). The role of education in ensuring skilled human capital for companies. Theoretical and Empirical Researches in Urban Management, 75-84.

Neave, G., \& Van Vught, F. (1994). Government and higher education relationships across three continents: The winds of change. Oxford: Pergamon Press, 1-21.

Nguyet, P., Ly, T., \& Thao, L. (2018). Human capital and provincial/city economic growth in Vietnam. Journal of Asian Business and Economics Research, 5-17.

OECD. (2009). OECD Reviews of Tertiary Education.

OECD. (2017). Population with tertiary education (indicator).

Permani, R. (2009). The Role of Education in Economic Growth in East Asia: a survey. SIANPACIFIC ECONOMIC LITERATURE, 23(1), 1-20.

Philip, G. (2009). One-third of the globe: The future of higher education in China and India. Prospects, 39(1), 11-31.

Pyo, H. (1995). A time series test of the endogenous growth model with human capital. The University of Chicago Press, 229-242.

Qiang , Q. (2018). Research on the Relationship between Financial Investment of Higher Education and Economic Growth in Fujian Province. Advances in Social Science, Education and Humanities Research, 182.

Research and Development Expenditure. (n.d.). Retrieved July 20, 2020, from tradingeconomics.com: https://tradingeconomics.com/

Rha, L., \& Byun, H. (2007). The contexts of implementing national human resources development in Korea. Journal of Lifelong Learning Society (in Korean), 3(2), 55-74.

SALARY ANALYZER. (n.d.). Retrieved 07 20, 2020, from Average Salary Survey: www.averagesalarysurvey.com

Shuang , L., Xiaoxia, L., \& Yi, S. (2018). Research on the Relationship between Higher Educational Investment and Economic Growth in Hebei Province based on the Comparative Analysis of Beijing-Tianjin-Hebei. International Symposium on Social Science and Management Inovation, Advances in Economics, Business and Management Research, 68, 620-627

Shuang Lu, X. L. (2018). Research on the Relationship between Higher Educational Investment and Economic Growth in Hebei Province based on the Comparative Analysis of Beijing-TianjinHebei. Proceedings of the 2018 International Symposium on Social Science and Management Innovation.

Su, Y., \& Liu, Z. (2016). The impact of foreign direct investment and human capital on economic growth: Evidence from Chinese cities. China Economics Review, 97-109.

Szarowska, I. (2016). The impact of public expenditure on research and development on economic growth in some countries. International Scientific Conference \& Business and Management 2016.

Trinh, N., \& Cicea, C. (2019). Budget allocation policy for public higher education in Vietnam: a short radiography and future trends. Paper presented at The 13th International Management Conference.

Vietnam Academy of Science and Education. (2016). Experiences of some countries on the development of higher education, science and technology in association with knowledge building. Hanoi: Hanoi National Political Publishing House.

Wang, BR; Wang , ZG;. (2013). Research on the Relationship between Higher Education and Regional Economy. PROCEEDINGS OF THE 2013 INTERNATIONAL CONFERENCE ON ADVANCES IN SOCIAL SCIENCE, HUMANITIES, AND MANAGEMENT. 
Wang, H., \& Gao, H. (2014 ). Empirical Research on the Higher Education and Regional Economic Growth in Jilin Province. 2014 INTERNATIONAL CONFERENCE ON BUSINESS, ECONOMICS AND MANAGEMENT (BEM 2014).

Wang, X., \& Liu, J. (2010). China's higher education expansion and the task of economic revitalization.

Wenli, L., \& Qiang , L. (2013). Chinese higher education finance: changes over time and perspectives to the future. Procedia-Social and Behavioral Sciences, 388-411.

Zhang , C., \& Zhuang , L. (2011). The composition of human capital and economic growth: Evidence from China using dynamic panel data analysis. China Economic Review, 165-171.

Zin, R. (2005). Income distribution in EastAsian developing countries: recent trends. Asian-Pacific Economic Literature, 36-54. 